\title{
Study on Evaluation System of College Teachers' Morality in the New Era*
}

\author{
Rui Xiong \\ Physics and Space Science College \\ China West Normal University \\ Nanchong, China 637002
}

\begin{abstract}
Through the analysis of the principles, approaches and methods for the development of university teachers' professional ethics assessment index system, the paper worked out the observation points, weights, and operational approaches of indicators at all levels in the college teachers' professional ethics assessment system in detail to fully explain how to develop professional ethics evaluation of university teachers.
\end{abstract}

Keywords-college teacher morality; evaluation system; construction; practice exploration

\section{INTRODUCTION}

In the process of realizing the goal of "China Dream" proposed by General Secretary Xi Jinping, colleges and universities undoubtedly played a pioneering, radioactive and exemplary role. The professional ethics level of college teachers is an important indicator of measuring the level of running a university and comprehensive strength. In December 2011, the Ministry of Education promulgated the Code of Professional Ethics for College Teachers, which has important practical significance for strengthening the selfcultivation of college teachers and the formation of noble professional ethics. To make the professional ethics construction of university teachers effective, it is necessary to establish a scientific and effective incentive mechanism and improve a reasonable system of professional ethics assessment for university teachers.

\section{PROBLEMS EXISTING IN THE PROFESSIONAL ETHICS ASSESSMENT OF COLLEGE TEACHERS}

China is currently in the transition period of social transformation, renewal of ideas, value conflicts, and moral transformation. Due to complex social factors, there are various inaccuracies in the evaluation of college teachers' professional ethics, which will seriously jeopardize the process of teachers' ethics construction. Although people have paid enough attention to improving the importance of college teachers' professional ethics assessment system, the actual situation is still not so desirable.

*Fund Project: scientific research project of Sichuan Provincial Department of Education "Study on the Evaluation System of College Teachers' Professional Ethics in the New Era" (Project No.: 14SB0097).

\section{A. The Professional Ethics Assessment System for College Teachers Needs to Be Improved}

The new educational concept has given new content to the construction of teachers' morality. Colleges and universities should update their ideas and keep pace with the times, so that the criteria for the evaluative criteria of professional ethics of university teachers in the new era are quickly established and improved. As an essential condition and important link for judging the construction status and effectiveness evaluation of the school teachers' morality, the professional ethics evaluation of college teachers is an indispensable external dynamic mechanism in the process of teacher ethics construction. It is the most important issue to establish an evaluation index system of college teachers' professional ethics that is both scientific and reasonable. The establishment of a good professional ethics assessment system for college teachers is the basis and premises for professional ethics assessment of college teachers. The existing professional ethics assessment system for college teachers is still not sound enough. It is mainly manifested in the one-sidedness of the professional ethics evaluation of university teachers. Choosing evaluation criteria and assessment methods one-sided cannot evaluate the professional ethics of university teachers fully and objectively neither can integrate various factors well to work together.

\section{B. The Value Orientation of College Teachers' Professional Ethics Assessment Is Unfair}

As a sensitive problem, the evaluation of every college teacher's ethic is not going to be very different, unless there is a special case. As the organizer of the assessment, the design of most college teachers' professional ethics assessment indicators often pays attention to scientific research quality and looks down on the effect of imparting knowledge and educating people, which exert a serious negative impact on the formation of a good outlook on life, world outlook and values of college students. To a certain extent, it is an assessment for evaluation. Some colleges and universities do not pay attention to the evaluation of teachers' morality. They have large slogans but no action. They only conduct an evaluation at the end of every semester. In terms of function, the target of college teachers' professional ethics assessment is too high, and all teachers are required to use a 
unified standard and norm, which has deviated from its guidance and motivation, and feedback evaluation results are often overlooked.

\section{The Fuzzification of College Teachers' Professional Ethics Evaluation Standard}

There are certain problems in the classification of teachers' morality in China. Some attribute the teachers' morality to the category of pedagogy and teacher ethics, and some attribute it to the category of ideological and political education. Different disciplines have different requirements on teacher's ethics. Therefore, the standards for the evaluation of the teacher ethics are different, and the professional ethics assessment standards for college teachers have appeared to be very vague and chaotic. In the assessment of college teachers' professional ethics, the first question to be solved is what kind of standard should be used to judge whether or not college teachers' behavior is moral, that is, to determine a scientific and reasonable standard for college teacher professional ethics assessment. Only when the standards are clear, can one to one correspondence be made and the assessment results obtained is objective and fair so as to truly achieve the purpose of the assessment.

\section{The Single Method of Professional Ethics Assessment for College Teachers}

In the current actual assessment work, the transparency of some teacher ethics evaluations is poor, resulting in most university teachers being ignorant of the assessment procedures, assessment methods and assessment results. The colleges make a casual assessment, or fill in a form and give a score, and then report to the school personnel department for approval after the leader signing. The scientific professional ethics evaluation system of university teachers requires the diversification of evaluation subject and evaluation methods. This is due to that a single evaluation method is difficult to be objective and fair.

\section{THE FORMULATION OF UNIVERSITY TEACHER PROFESSIONAL ETHICS EVALUATION INDEX SYSTEM}

Moral evaluation of college teachers is a practical activity that people make judgments between good and evil and determine their moral values according to certain standards. It refers to the establishment of a standardized mechanism for the professional ethics of university teachers, and then conducts an objective and scientific assessment. It's a process of assessing the morality of college teachers on the basis of the evaluation standards by applying different methods according to a certain procedure.

\section{A. Construction Method of Professional Ethics Assessment Index of College Teachers}

The professional ethics assessment of college teachers is a comprehensive system and is not independent. The premise and basis of the assessment are to decompose and specify the goals. Each aspect has a corresponding target project, which is divided into first, second, and third levels. The upper-level goal is divided into multiple secondary target projects, and each secondary target project includes several third-level projects. The target hierarchy system needs to use the principles of evaluation index system construction on the basis of university teachers' professional ethics to translate itself into specific evaluation indicators. In this way, the objectives, functions and index of college teachers' professional ethics assessment can be fully integrated.

By adopting the expert opinion, the goal decomposition of the evaluation index system construction is revised to ensure the scientificness of the professional ethics evaluation index system for college teachers. Through issuing questionnaires to secretaries and deans of the secondary colleges, leaders and executors in charge of personnel work in colleges and universities, as well as experts in student management and ideological and political education, firstly, the second-level indicators and weights recognized by most experts can be determine, amendments can be obtained by asking the experts, and the questionnaires can be collected and organized; Next, the three-level indicators, weights and scores that are recognized by most experts can be determined, and amendments are proposed by experts and arranged again. In this way, through the repeated use of the expert opinion method, not only the specific contents of indicators at all levels of university teachers' professional ethics assessment system can be completed, their weights and scores can also be determined.

\section{The Basic CONTENT OF COLlege Teachers' MORAL ASSESSMENT INDICATORS}

According to the method of constructing professional ethics assessment indicators for college teachers, decomposing the objectives of the "Code of Professional Ethics of College Teachers" and repeatedly consulting experts, we gradually built up six primary targets: patriotism and observance of law, Professionalism and loving students, serving the society, imparting knowledge and educating people, rigorous scholarship, and stand and deliver, nineteen secondary indicators, and sixty-four three-level single assessment sub-index of college teachers' ethical assessment index system, as well as six overall indicators and specific second and third indicator scores and weight content.

\section{THE OPERATION PRACTICE OF UNIVERSITY TEACHERS' PROFESSIONAL ETHICS ASSESSMENT}

In practical use, it is necessary to set up a special agency responsible for formulating specific operating systems and regulations in order for the evaluation of teacher ethics to be carried out in an orderly manner and receive the desired results. Before the evaluation begins, it is necessary to further clarify the guiding ideology of the assessment, compile an appraisal handbook (developing a table for teachers and students according to the content of university teacher' professional ethics assessment indicators), establish an assessment team, determine the assessment subject, and choose the evaluation time, etc. 


\section{A. Establishing Two-level Institutions of the University and College to Take Charge of the Professional Ethics Evaluation of College Teachers}

Led by the Personnel department, cooperating with dean's office, students' affairs office, publicity department and other departments, colleges are responsible for the work at the university level. Combined with the characteristics of the new period, they put forward specific requests from six aspects of "Code for the Professional Ethics of University Teachers" in accordance with the requirements of teacher's ethics construction. Secondary schools should set up a leading group of professional ethics assessment for university teachers in the charge of Secretary of Party General Branch, attended by executive directors, union leader, secretary of league general branch, teachers and student representatives to carry out the teachers' moral evaluation in the unit and formulate specific implementation plans as well as put them into practice based on the actual situation of the unit.

\section{B. Determining the Assessment Subject of University Teachers' Professional Ethics Assessment}

Through the method of expert consultation, each subject and their weight allocation of the professional ethics assessment of college teachers are determined. They are composed of individuals, college colleagues, university leaders, and students.

1) Self-assessment: Self-assessment is the core of teacher professional ethics evaluation in colleges and universities. In the assessment process, college teachers themselves are both targets of evaluation and evaluators. College teachers are the designers and implementers of educational activities. They know best about the actual effects of education and are most aware of what they think about their jobs. The self-evaluation weight is 0.2 .

2) Assessment of Colleagues in the Same College: As peers and colleagues, they have a better understanding of the work status of the assessed objects, so the specific conditions of the assessed objects can be reflected more accurately, and they can learn from each other and improve together during the assessment process. Colleague assessment weight is 0.3 .

3) Assessment of the College Leaders: The assessment of the college leaders mainly consists of the dean who understands the faculty's work well, various relevant department heads, and the experts employed by the school. School assessment weight is 0.3 .

4) Student Assessment: Student assessment can adopt the method of all student questionnaires, and it can also adopt random sampling questionnaires. Online voting assessments using the campus network, anonymous questionnaire surveys and registered scoring assessments can also be conducted, with a student assessment weight of 0.2 .

\section{Procedures for Assessing the Professional Ethics of University Teachers}

The professional ethics assessment of college teachers has six steps:

1. Making a "Self-assessment Form for College Teachers' Professional Ethics Assessment" and send it to the teachers who are evaluated, and arranging the teachers to report their ethics performance to all colleagues in the teaching and research office according to the prescribed project.

2. In accordance with the conditions known in the ordinary times, all teachers in the teaching and research office make an objective assessment for the teachers that are evaluated, fill out the "Self-assessment Form for College Teachers' Professional Ethics Assessment", and provide anonymous scores.

3. All students fill out a "Student evaluation form of College Teachers' Professional Ethics Assessment" to comment on the ethics performance of the evaluated teachers and provide scores in the bearer form.

4. Based on the comments of teaching and research office and students, the evaluation leading group makes final comments on the assessed teachers, and provides assessed scores in the bearer form.

5. The final assessment scores are calculated according to the weight distribution of the various indicators of the evaluation system, and the assessment scores are obtained. On the basis of the scores, the assessment organization will make a comprehensive qualitative assessment conclusion, publish it within the school, and report it to the personnel department of the school to keep in the archives for reference.

6 . If the teacher who has been assessed has any objection to the assessment result, it may submit a review within three days based on the specific basis. The assessment team should ascertain whether it is true immediately and give a reply within five working days.

\section{Discipline of Professional Ethics Evaluation of College Teachers}

The professional ethics evaluation of university teachers is a systematic project. It not only needs the overall planning of school party committees and administrative departments, but also the joint efforts of various functional departments and faculties. In the assessment process, there must be specific persons to manage the collection of the usual situation and the filing of evaluation materials to ensure that the professional ethics assessment of university teachers can be carried out smoothly, and in the meanwhile, pay attention to the confidentiality. Teachers must report all kinds of materials truthfully. If falsified, they should be given deduction on points. If the circumstances are serious, the teachers related should be given a non-conformity assessment. 


\section{APPLYING THE ASSESSMENT RESULTS OF PROFESSIONAL ETHICS OF UNIVERSITY TEACHERS EFFECTIVELY}

Giving full play to the role of college teachers' professional ethics assessment and social supervision, assessing the professional ethics of university teachers scientifically, only in this way, the construction of professional ethics of university teachers can be strengthened. The assessment of college teachers' professional ethics should be linked with the teachers' annual assessment of professional title appraisal, salary promotion, promotion, study abroad, award evaluation and so on. Schools and departments can regularly select "most popular teachers with students", "teacher's ethics model" and give them certain incentives for bonuses according to the conditions of their own units. For the excellent teachers in the evaluation, they should be given priority on some aspects such as promotion of titles, visiting abroad, further study, and identifying key teachers. In the evaluation of college teachers' professional ethics, the practice of replacing construction by punishment in some schools or departments should be changed, and the idea of improving construction through evaluation should be reflected in order to enhance teachers' awareness of professional ethics constantly. The evaluation of professional morality in colleges and universities gives a demonstration and vigilance on professional ethics and encourages college teacher to be strict self-disciplined, which create a good atmosphere for the construction of teachers' morality and ultimately promote the professional ethics of college teachers.

\section{CONCLUSION}

In short, scientifically conducting professional ethics assessment activities of university teachers is undoubtedly one of the most effective ways to improve college teachers' professional ethics, improve the professional ethics status quo of college teachers, and optimize the quality of education and teaching. Therefore, it's urgent for us to mobilize the collective forces in all aspects of the society to work together to establish a fair, reasonable, scientific, and perfect system of professional ethics assessment for university teachers. Only by establishing such a comprehensive and systematic system of moral evaluation for university teachers and continue to enrich and perfect the various indicators of the evaluation system, the invisible spiritual power of the moral assessment can be brought into full play to lead higher education in China to a higher level.

\section{REFERENCES}

[1] Wang Qingfeng. Disscussion on the Construction of Teacher's Professional Ethics Evaluation Mechanism [J]. Journal of Qinghai Normal University 2011,(11):131-133. 王清. 风试论教师职业道德评 价机制的建构 [J]. 青海师范大学学报 2011,(11):131-133.

[2] Yue Qiang. Some Inspirations from the Code of Professional Ethics for Teachers in the United States [J]. Modern Communication. 2011, (11): 322. 岳强. 从美国教师职业道德规范中得到的几点启示 [J]. 现代交际. 2011,(11):322.

[3] Zhou Mingliang. Chi Chengyong. The Connotation of Teacher Morality Construction in Vocational Colleges in New Period and Its
Evaluation Mechanism [J]. 2011,(07). 周明亮. 迟成勇. 新时期高职 院校师德建设内涵与评价机制构建 [J]. 2011,(07).

[4] Pang Mingzhen. Xie Tingfen. Exploration on Teacher Evaluation System of Universities and the Construction of Teacher's Morality [J]. 2011，(9). 庞明珍. 谢廷芬. 高校教师评价体系与师德建设探究 [J]. 2011,(9).

[5] Guo Xiuqin. Research on Young Teachers' Morality Construction in Colleges and Universities in the New Period [J]. Management \& Technolosy of SME (First Edition) 2010, (12). 郭秀琴. 新时期高校 青年教师师德建设研究 [J]. 中小企业管理与科技 (上旬刊) 2010,(12).

[6] Zhou Lichun. The Significance and Methods of Strengthening Teachers' Moral Construction in Colleges and Universities under the New Situation [J]. School Party Construction and Ideological Education 2010, (35). 周礼春. 新形势下加强高校师德建设的意义 及方法 $[\mathrm{J}]$. 学校党建与思想教育 2010,(35). 